DOI: https://doi.org/10.32839/2304-5809/2019-2-66-12

UDC $81-13$

Badziyk Iryna

Lesya Ukrainka Eastern European National University

\title{
LEGAL DISCOURSE OF THE EUROPEAN UNION AS AN OBJECT OF LINGUISTIC RESEARCH
}

Summary. The EU legal language is probably one of the most visible examples of technical language composed by legal words - concepts - entirely created by social interaction and legitimated by collective consent - actorsinvolved in the legislative process. The European Union law discourse is oriented towards the whole society and is considered one of the most relevant contemporary discourses. After all, law is not only a set of normative acts and laws, but also the most important achievement of the culture of all civilization, which should be a firm foundation for the life of society as a whole. It is EU legislation that makes a significant contribution to the legal terminology of the European Union states, which creates new and modern universal terms. They facilitate their use in a particular state and increase their effectiveness in practice. The article analyzes and highlights the features of the legal discourse of the European Union and other English-speaking states. Also defined strategy, subject area and goals of legal discourse. As a result of globalization processes and European integration, the volume of interlingual communication is increasing, which, in its turn, requires thorough research in general and the translation of legal and other terms. Despite a large number of studies of this problem, there are not enough scientific works devoted to the study of the features of English legal discourse. The object of our analysis is the original English-language legal acts of the European Union (Directives, Regulations), and the subject is the European legal discourse in its entirety. Actuality of theme is that there was a need for proper coverage of the important aspects of legal discourse and its characteristic features among other types of discourses in connection with the growing role of the European legal system and its influence on the formation of legal discourse. Legal discourse is understood as activity regulated by certain historical and socio-cultural codes (traditions); It is aimed at formulating norms, legal consolidation (legitimization), regulation and control of public relations in the field of jurisprudence.

Keywords: legal discourse, Directive, The European Union, term, law.

Бадзюк I.C.

Східноевропейський національний університет імені Лесі Українки

\section{ЮРИДИЧНИЙ ДИСКУРС ЄВРОПЕЙСЬКОГО СОЮЗУ ЯК ОБ'ЄКТ ЛІНГВІСТИЧНИХ ДОСЛІДЖЕНЬ}

\begin{abstract}
Анотація. У статті досліджено правову мову Свропейського Союзу, як а е, ймовірно, одним з найбільш помітних прикладів технічної мови, яка поєднує у собі правові поняття, визначення, які створені завдяки соціальній взаємодії і колективними угодами, а саме учасниками законодавчого процесу. Правовий дискурс Свропейського Союзу орієнтований на все суспільство і вважається одним з найбільш актуальних сучасних дискурсів. Адже, право - це не тільки сукупність нормативних актів та законів, а й найважливіше досягнення культури всіеї цивілізації, яка повинна бути міцним фрундаментом для суспільства в цілому. Саме законодавство Свропейського Союзу робить значний внесок у юридичну термінологію країн Свропейського Союзу, яка створюе нові та сучасні універсальні терміни. Вони полегшують їх використання в певному стані і підвищують їх ефективність на практиці. Також у статті проаналізовано та виділено особливості юридичного дискурсу Свропейського Союзу та інших англомовних держав, визначена стратегія, предметна область та цілі юридичного дискурсу. Внаслідок процесів глобалізації та європейської інтеграції зростае обсяг міжмовної комунікації, яка, в свою чергу, вимагає грунтовних досліджень в цілому та перекладу юридичних та інших термінів. Незважаючи на значну кількість досліджень зазначеної проблеми, недостатньюю е кількість наукових робіт, присвячених вивченню особливостей англомовного юридичного дискурсу. Об'єктом нашого аналізу є оригінальні англомовні законодавчі акти Свропейського Союзу (Директиви, Регламенти), а предметом є власне європейський юридичний дискурс у всіх його проявах. Актуальність дослідження полягае в тому, що виникла потреба у належному висвітленню важливих аспектів юридичного дискурсу та його характерних особливостей серед інших видів дискурсів у зв'язку із зростанням ролі Свропейської правової системи та впливу її на формування юридичного дискурсу. Під юридичним дискурсом розуміємо діяльність, яка регламентується певними історичними і соціокультурними кодами (традиціями); вона спрямована на формулювання норм, правове закріплення (легітимізацію), регулювання та контроль суспільних відносин у сфері юриспруденції.
\end{abstract}

Ключові слова: юридичний дискурс, Директива, Свропейський Союз, термін, право.

Droblem. There are several features of a modern society: the global absorption of any information and the global discussion of events and resonance phenomena and facts. To these features we add another one that is clearly traceable today in connection with each event at the national and international levels in the context of law. This is a problem of law enforcement practice, which is related to the interpretation of the Directives and Regulations of the European Union.

Analysis of recent research and publications. Issues of legal discourse were dealt with Koval N.E., "Communicative-pragmatic aspects of legal discourse", Dorda S. "On some peculiarities of legal discourse", Kravchenko N.K. "International-legal discourse: cognitive-communicative aspect" and others. 
The aim of the article is The European Union law discourse which is oriented towards the whole society and is considered one of the most relevant contemporary discourses. After all, law is not only a set of normative acts and laws, but also the most important achievement of the culture of all civilization, which should be a firm foundation for the life of society as a whole. It is EU legislation that makes a significant contribution to the legal terminology of the European Union states, which creates new and modern universal terms.

To begin with we want to say that there are several features of a modern society: the global absorption of any information and the global discussion of events and resonance phenomena and facts. To these features we add another one that is clearly traceable today in connection with each event at the national and international levels in the context of law. This is a problem of law enforcement practice, which is related to the interpretation of the Directives and Regulations of the European Union. It is they that are globally dynamic, and at the same time, those that give rise to various interpretative debates, through the dissonance of the meanings written and adopted.

'Legal discourse' signifies a strong interplay between law and language, linking together law as like language and law as itself language. The language of the law is a prominent indicator of the social and historical genesis and motivation of the legal text as instrument of social regulation and discipline. Legal discourse, like any other of the traditional rhetorical genres or language varieties, is an historically and rhetorically organised product.

The EU legal terminology providing rights comes into being through specific mechanisms of lexical creation, which chiefly consist of semantic neologisms. All legal texts must be written in accordance with EU drafting guidelines, prescribing that "rules have to be drafted bearing in mind their translation in all the official languages" $[1, p$. 7]. The consequence of these drafting techniques is that multilingualism influences not only the translation, but the actual structure and content of the rule: very often the result of this praxis is a pragmatic, detailed, concrete regulation of legal instruments, rather than a system of rights.

The multilingual drafting of EU norms - and consequently of EU rights - is not automatically functional to the effective transposition of rights in the Member States and to the substantive equality of EU citizens before European law. The EU language is bound to the inner grammar of the legal system of the European Union, to its policy, form of government, drafting techniques and, last but not least, to the multilingualism mission. Rules and concepts, as well as the variables that affect the evolution of the EU language, originate in many non-legal environments. Current evidence suggests that EU legal discourse is considered a technical legal language, yet not completely elaborated.

The most crucial feature marking legal discourse off from all other subtypes of (specialized) language is that it is endowed with legal force. Thus, the task of a legal translator is to re-create a source text content in the target text in such a manner so that it represents its legal equivalent with identical legal effects. While lay people com- monly think of legal language as abstruse, arcane or grave, experts speak of its template-like and clichéd nature which is in particular attributed to legal phraseology, schematicity and repetitiveness of certain textual elements. Matilla [2, p. 104] associates it with "archaic verbal magic" and treating "language as a fetish". Thus, the reliance on a set of fixed phrases greatly contributes to the perception of legal language as a "frozen genre" [3, p. 24] or "fossilized language" [4, p. 76]. Accuracy is of supreme importance in legal translation and takes precedence over stylistic considerations [5]: "It is agreed that substance must always prevail over form in legal translation". In more recent approaches to legalese, accuracy as to the information content (equivalence) is apprehended as "the presumption of equal intent" and the 'spirit' rather than the 'letter' of the law [5].

The legal discourse of the European Union differs from the legal discourse of other English-speaking countries (for example, The United Kingdom of Great Britain and Norther Islands). The legal terminology of the common law countries often does not coincide with the concepts and terms of continental law. For example, the definition of "trader" in the law of the UK sounds different from the European Union. In the document «The Consumer Contracts» (Information, Cancellation and Additional Charges) Regulations 2013 No. 3134 UK Statutory Instruments [6], defenition "trader" means a person acting for purposes relating to that person's trade, business, craft or profession, whether acting personally or through another person acting in the trader's name or on the trader's behalf.

In Directive 2013/11/EU of the European Parliament and of the Council of 21 May 2013 on alternative dispute resolution for consumer disputes and amending Regulation (EC) No 2006/2004 and Directive 2009/22/EC [7]) 'trader' means any natural persons, or any legal person irrespective of whether privately or publicly owned, who is acting, including through any person acting in his name or on his behalf, for purposes relating to his trade, business, craft or profession. It follows that some definitions of the same legal terms differ in their essence. It depends on the state system.

There are several Directives that define the term "Consumer". The wording differs somewhat in the different directives. The starting point has been the definition in the door-to-door selling directive, where the consumer is defined as "a natural person who, ..., is acting for purposes which can be regarded as outside his trade or profession" (Art. 2) [8]. An identical definition can be found in Art. 1(2) in the consumer credit directive [9].

In the unfair contract terms directive,[10] the consumer is defined as "a natural person who, ..., is acting for purposes which are outside his trade, business or profession" (Art. 2(b)). The same definition is given in Art. 2(2) in the distance contracts directive and in Art. 1(2)(a) in the consumer sales directive [11]. The only difference between this definition and the one in the door-to-door selling directive and the consumer credit directive is that the unfair contract terms directive and the distance contracts directive are also applicable when the person is acting outside his "business". 
Because of this Council Directive 85/577/EEC was canceled. Instead of it was adopted a number of new directives of the EUROPEAN UNION in which the term "consumer" in its meaning was the same. For example, in Directive 2008/48/EC of the European Parliament and of the Council of 23 April 2008 on credit agreements for consumers and repealing Council Directive 87/102/EEC and in Directive 2011/83/EU of the European Parliament and of the Council of 25 October 2011 on consumer rights, amending Council Directive 93/13/EEC and Directive 1999/44/EC of the European Parliament and of the Council and repealing Council Directive 85/577/EEC and Directive 97/7/EC of the European Parliament and of the Council Text with EEA relevance the term "consumer" means the same - "any natural person who, in contracts covered by this Directive, is acting for purposes which are outside his trade, business, craft or profession";

In this regard, now there is no problem with the interpretation of this term. Consequently, the legal discourse of the European Union is improved year by year and becomes more understandable for member countries.

A clear definition from the beginning would have helped to develop consumer protection. With the definitions provided by the directives the national states gain had to determine what must be understood by the notion of a "consumer". Legal linguistic standardization within the European Union will help to keep integration growing. From the example of the notion of a consumer we can see that there is a clear need for review of the existing acquis communautaire and for standardization.

The main component of legal discourse is the text of a legal document, which is an impetus for the social and legal development of society. The source of legal texts is professional lawyers who create these texts, taking into account the specifics of the structure of society. The status of law is extremely high and responsible, his language is an indicator of the level of the culture of lawmakers. During the formulation of laws, their authors are simply obliged to adhere to the existing norms of language system.

Participants in legal discourse differ from communicators of other types of discourse:

1. The addressee of the legal discourse of the European Union - is a mass (generalized) and at the same time sufficiently defined addressee (every citizen of an individual state which is a member of European Union).

2. Knowledge in the field of law (use the legal language).

3. Legal texts are intended for all citizens, so they should be clear in content and easy to understand.

In 2015 was adopted "Joint Practical Guide» of the European Parliament, the Council and the Commission for persons involved in the drafting of European Union legislation. It means that the legal acts drawn up by the European Parliament, the Council and the Commission are drafted clearly and precisely. The Joint Practical Guide is a platform of general drafting principles. Each institution uses the guide alongside other instruments which contain specific standard formulations and more detailed practical rules. The drafting of a legal act must be: clear, easy to understand and unambiguous; simple and concise, avoiding unnecessary elements; precise, leaving no uncertainty in the mind of the reader. In order to be able to express the legislative intention in simple terms, the drafter should try to break it down into simple concepts. Whenever possible, everyday language should be used. Where necessary, clarity of expression should take precedence over considerations of style. For example, the use of synonyms and different expressions to convey the same idea should be avoided.

Overly complicated sentences, comprising several phrases, subordinate clauses or parentheses (interpolated clauses) should also be avoided. Example of drafting to be avoided: 'All parties to the agreement must have access to the results of the work, subject to the understanding that research institutes have the possibility to reserve use of the results for subsequent research projects.'Better drafting: 'All parties to the agreement shall have access to the results of the work. However, research institutes may reserve use of the results for subsequent research projects.'

There should be no doubt, for example, as to whether an adjective relates to a single noun or to several. Example of drafting to be avoided: '...public parks and hospitals...' Better drafting: '...public parks and public hospitals... [1]. All these rules help to creat better understood and correctly implemented legislative acts. Also we can see that all these and other rules separate the legal discourse of the European Union from other types of discourse. It has its own purpose, defined participants and a speech situation. Legal discourse is understood as the text of law in dynamics, in the process of interpretation and explanation.

Conclusion. The EU legal language is probably one of the most visible examples of technical language composed by legal words - concepts - entirely created by social interaction and legitimated by collective consent - actorsinvolved in the legislative process. We highlight the following main features of legal discourse:

- social, political, cultural predestination;

- structured terminology system;

- non-transparency of interpretations and interpretations;

- dynamic development.

Therefore, it should be noted that the legal discourse of the European Union is to create new terms based on the correlation between the already existing terminology of the member states, which in turn is intended to create a single legal system that is simple and comprehensible to all EU member states.

The European Union law discourse is oriented towards the whole society and is considered one of the most relevant contemporary discourses. After all, law is not only a set of normative acts and laws, but also the most important achievement of the culture of all civilization, which should be a firm foundation for the life of society as a whole. It is EU legislation that makes a significant contribution to the legal terminology of the European Union states, which creates new and modern universal terms. They facilitate their use in a particular state and increase their effectiveness in practice. By doing so, some European Union bodies, for example, the European Court of Justice, by way of judgment, give an example to other Member States in the application of certain EU legislation. It should be not- 
ed that legal discourse has its social, political, cultural precondition; structured terminology system; in some cases, different interpretations; dynamic development. Legal discourse belongs to the type of institutional discourse that relates to the sphere of regulation of social relations and is characterized by a rigid organization and hierarchical structure. It is oriented to all strata of society and is considered one of the most relevant discourses discourse in the modern world.

\section{References:}

1. Joint Practical Guide of the European Parliament, the Council and the Commission for persons involved in the drafting of European Union legislation. URL: https://eur-lex.europa.eu/content/techleg/EN-legislative-drafting-guide.pdf

2. Mattila, Heikki E.S. (2006). Comparative Legal Linguistics. Aldershot: Ashgate Aldershot, Hampshire \& Burlington VT, Ashgate Publishing Limited \& Ashgate Publishing Company, 2006. ISBN-10: 0754648745 \& ISBN-13: 978-0-7546-4874-1

3. Bhatia, Vijay K. (2004). Worlds of Written Discourse. London : Continuum.

4. Alcaraz, Enrique and Hughes, Brian (2002). Legal Translation Explained. Manchester : St. Jerome Publishing, p. 204.

5. Sarcevic, Susan (2000). Legal Translation and Translation Theory: a Receiver-oriented Approach [online]. [cit. 2014-9-28].

6. The Consumer Contracts (Information, Cancellation and Additional Charges) Regulations 2013 No. 3134 UK Statutory Instruments. URL: http://www.legislation.gov.uk/uksi/2013/3134/contents/made?text=trader\#match-1

7. Directive 2013/11/EU of the European Parliament and of the Council of 21 May 2013 on alternative dispute resolution for consumer disputes and amending Regulation (EC) No 2006/2004 and Directive 2009/22/EC. URL: http://eur-lex.europa.eu/legal-content/EN/TXT/?qid=1497379412951\&uri=CELEX:32013L0011

8. Directive 2011/83/EU of the European Parliament and of the Council of 25 October 2011 on consumer rights, amending Council Directive 93/13/EEC and Directive 1999/44/EC of the European Parliament and of the Council and repealing Council Directive 85/577/EEC and Directive 97/7/EC of the European Parliament and of the Council. URL: https://eur-lex.europa.eu/legal-content/EN/TXT/PDF/?uri=CELEX:32011L0083

9. Directive 2008/48/EC of the European Parliament and of the Council of 23 April 2008 on credit agreements for consumers and repealing Council Directive 87/102/EEC Council Directive 93/13/EEC. URL: https://eur-lex.europa.eu/ legal-content/EN/TXT/PDF/?uri=CELEX:32008L0048\&rid=1

10. Directive 97/7/EC of the European Parliament and of the Council of 20 May 1997 on the protection of consumers in respect of distance contracts (OJ L 144, 4.6.1997, p. 19. URL: http://www.worldbiz.ru/base/24144.php

11. Directive 1999/44/EC of the European Parliament and of the Council of 25 May 1999 on certain aspects of the sale of consumer goods and associated guarantees. See also Art. 2(e) Directive on Electronic Commerce 2000/31/EC, where a consumer is defined as "any natural person who is acting for purposes which are outside his or her trade, business or profession". URL: https://eur-lex.europa.eu/legal-content/EN/ALL/?uri=CELEX\%3A31999L0044 